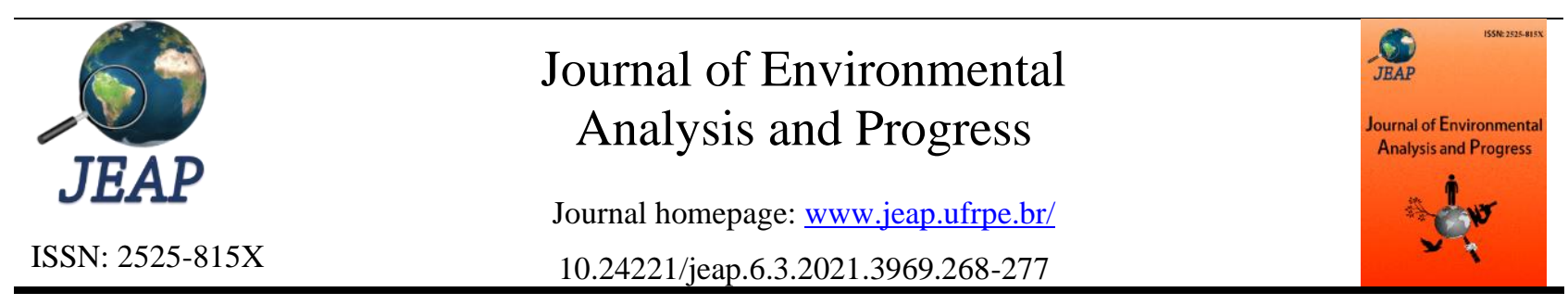

\title{
Anatomical and histochemical characterization of leaves of Spondias purpurea $\mathrm{L}$.
}

\author{
Gleyka Daisa de Melo Santosa, Cledson dos Santos Magalhãesa, Rafaela Damasceno Sáa, Karina \\ Perrellli Randau ${ }^{\mathrm{a}}$ \\ ${ }^{\text {a } U n i v e r s i d a d e ~ F e d e r a l ~ d e ~ P e r n a m b u c o-U F P E, ~ D e p a r t a m e n t o ~ d e ~ C i e ̂ n c i a s ~ F a r m a c e ̂ u t i c a s, ~ L a b o r a t o ́ r i o ~ d e ~ F a r m a c o g n o s i a . ~}$ \\ Av. Prof. Arthur de Sá, S/N, Cidade Universitária, Recife-PE, Brasil. CEP: 50740-521. E-mail: \\ karina.prandau@ufpe.br.
}

A R T I C L E I N F O
Received 25 Nov 2020

Accepted 20 Apr 2021

Published 16 Sep 2021

\begin{abstract}
A B S T R A C T
The Anacardiaceae family has species-rich in secondary metabolites. They are widely used in popular medicine. Among them, Spondias purpurea L. stands out for containing several secondary metabolites with important biological activities. A precise identification of the species was the objective of this study, to perform an anatomical and histochemical characterization of leaves of $S$. purpurea. Microscope slides containing cross-sections of the petiolule and leaflets, in addition to paradermal sections of the leaflets, were prepared and analyzed in an optical and polarized microscope. Histochemical tests were performed on fresh leaflets. The microscopic analysis identified the anatomical structures to a diagnosis of the studied species, such as petiolule with concave-convex shape, non-glandular and glandular trichomes, druses in phloem; leaflets amphistomatic, with non-glandular trichomes on the adaxial face and glandular trichomes on the abaxial face, midrib with concaveconvex shape, two collateral vascular bundles, one layer of palisade parenchyma, druses in phloem and mesophyll. The histochemical analysis evaluated phenolic compounds, alkaloids, tannins, triterpenes, steroids, lipophilic compounds, essential oils, lignin, starch, and calcium oxalate crystals, evidenced in the leaflets. The results are important for the quality control of plant material and expand the knowledge about the species.
\end{abstract}

Keywords: Anacardiaceae, pharmacobotany, quality control.

\section{Introduction}

Spondias purpurea $\mathrm{L}$. is a fruit tree about three to five meters in height, a native of Central America. It can be commonly found in the northeastern region of Brazil (Lorenzi, Lacerda \& Bacher, 2015; Fortuny-Fernández, Ferrer \& Ruenes-Morales, 2017). Depending on the location, it may be known as red mombin, purple mombin, ciruela, seriguela, ciriguela, and jocote (Silva et al., 2014; Lorenzi, Lacerda \& Bacher, 2015; Marisco \& Pungartnik, 2015; Mitchell \& Daly, 2015).

The plant belongs to the family Anacardiaceae, a tropical and subtropical distribution, including about 80 genera and 873 species (Pell et al., 2011; APG IV, 2016). In Brazil, there are 14 genera and 53 species (Silva-Luz \& Pirani, 2015). Among them, several fruits of economic importance stand out, such as the cashew tree (Anacardium occidentale L.), the mango tree
(Mangifera indica L.), the group of ambarella (Spondias spp.), and pistachio (Pistacia vera L.) (Lorenzi, Lacerda \& Bacher, 2015).

From a phytochemical point of view, species of the Anacardiaceae family are rich in secondary metabolites, particularly phenolic compounds, with interesting biological activities. Therefore, many species of this family have also been used as medicinal plants to treat infectious diseases and as an anti-inflammatory (Silva et al., 2014; Schulze-Kaysers, Feuereisen \& Schieber, 2015; Sameh et al., 2018).

In Brazil, the leaves of $S$. purpurea have traditionally been used to treat gastritis (Borges \& Moreira, 2016; Castro et al., 2011), hypertension (Silva et al., 2012; Marisco et al., 2017b) and diarrhea (Franco \& Barros, 2006; Oliveira, Barros $\&$ Moita Neto, 2010; Freitas et al., 2012). Pharmacological studies have demonstrated its antimicrobial (Alencar et al., 2015; Miranda-Cruz 
et al., 2012; Marisco et al., 2017a; Santos, Santos \& Silva, 2017), antitumor (Santos, Santos \& Silva, 2017), antioxidant and antiulcer potential (Almeida et al., 2017).

In a literature review, Silva et al. (2014) showed that the most studied species of Spondias are $S$. mombin L., S. pinnata (L.f.) Kurz, and $S$. tuberosa Arruda, mainly in the areas of ethnobotany and pharmacology. There are also in the literature some anatomical and histochemical studies of Spondias species that highlight the importance of knowing the microscopic characteristics of these medicinal species, which can aid in taxonomy and quality control of plant material (Nascimento-Silva \& Paiva, 2007; Nascimento-Silva, Chinalia \& Paiva, 2008; Norfaizal \& Latiff, 2013; Chisom, Chukwu \& Okeke, 2014; Vasconcelos, Vasconcelos \& Randau, 2016). However, no data have been found in the literature about the microscopic identification of $S$. purpurea. Therefore, the objective of the present study was to perform an anatomical and histochemical characterization of leaves of $S$. purpurea.

\section{Material and Methods}

The plant material was collected in the city of Vitória de Santo Antão, Pernambuco, Brazil. A voucher specimen $\mathrm{n}^{\circ} 91797$ was deposited at the Herbarium Dárdano de Andrade Lima of the Instituto Agronômico de Pernambuco.

For anatomical characterization, several expanded leaves, collected in April 2018 between the third and fifth nodes from three specimens, were fixed in FAA50 (formaldehyde, acetic acid, and ethyl alcohol 50\%, 1:1:18 v/v) (Johansen, 1940). Cross-sections at the middle region of the petiolule and leaflets were obtained by freehand, using a common razor blade and the medulla of Cecropia sp. petiole as a support material. For the leaflets, paradermal sections were also performed on the adaxial and abaxial faces. Subsequently, the sections were submitted to a sodium hypochlorite solution (50\%) for discoloration (Kraus \& Arduin, 1997). After washing in distilled water, the crosssections were stained according to a technique described by Bukatsch (1972), using safranin and Astra blue. The paradermal sections were stained with methylene blue (Krauter, 1985). All sections were mounted on semipermanent slides following usual procedures in plant anatomy (Johansen, 1940; Sass, 1951). A light and polarization microscope (Leica DM750M), coupled with a digital camera (Leica ICC50W), was used to analyze the semipermanent histological slides. The images were processed in the software LAS EZ.

Histochemical tests were performed in cross-sections at the middle region of fresh leaflets collected from three specimens between the third and fifth nodes. The following reagents were used to indicate the presence of metabolites: potassium dichromate $(10 \%)$ for phenolic compounds (Johansen, 1940), Dragendorff's reagent for alkaloids (Yoder \& Mahlberg, 1976), vanillin chloridric for tannins (Mace \& Howell, 1974), antimony trichloride for triterpenes and steroids (Mace, Bell \& Stipanovic, 1974), Sudan III for lipophilic compounds (Sass, 1951), Nadi reagent for essential oils (David \& Carde, 1964), Lugol for starch (Johansen, 1940), phloroglucinol for lignin (Johansen, 1940), and hydrochloric acid (10\%) to establish the nature of the crystals (Jensen, 1962). Controls were performed parallel to histochemical tests, and semipermanent slides were prepared to contain cross-sections of the material (Johansen, 1940; Sass, 1951). The analysis of the images was conducted using the Toup View Image software. The images were obtained by a digital camera coupled to an optical light microscope (Alltion).

\section{Results and Discussion}

The $S$. purpurea petiolule has a concaveconvex shape in the transversal section, with two small lateral projections on the adaxial side (Figure 1A). The S. mombin petiolule showed a convex symmetry with undulation (Vasconcelos, Vasconcelos \& Randau, 2016). The epidermis is uniseriate and covered by a thin layer of the cuticle (Figure 1A). There are non-glandular and glandular trichomes, both being uniseriate and multicellular (Figure 1B). Only non-glandular trichomes were observed in S. mombin (Vasconcelos, Vasconcelos \& Randau, 2016). Parenchyma fills the entire petiolule (Figure 1A). There are collateral vascular bundles arranged in a ring shape in the central region (Figure 1A). In the phloem, there are secretory cavities and druses (Figure 1CD). The presence of secretory structures is a characteristic of the Anacardiaceae family (Metcalfe \& Chalk, 1950; Dantas et al., 2019; Sá et al., 2019). Druses have also been found in the petiolule of $S$. mombin, but are located close to the epidermis (Vasconcelos, Vasconcelos \& Randau, 2016). 


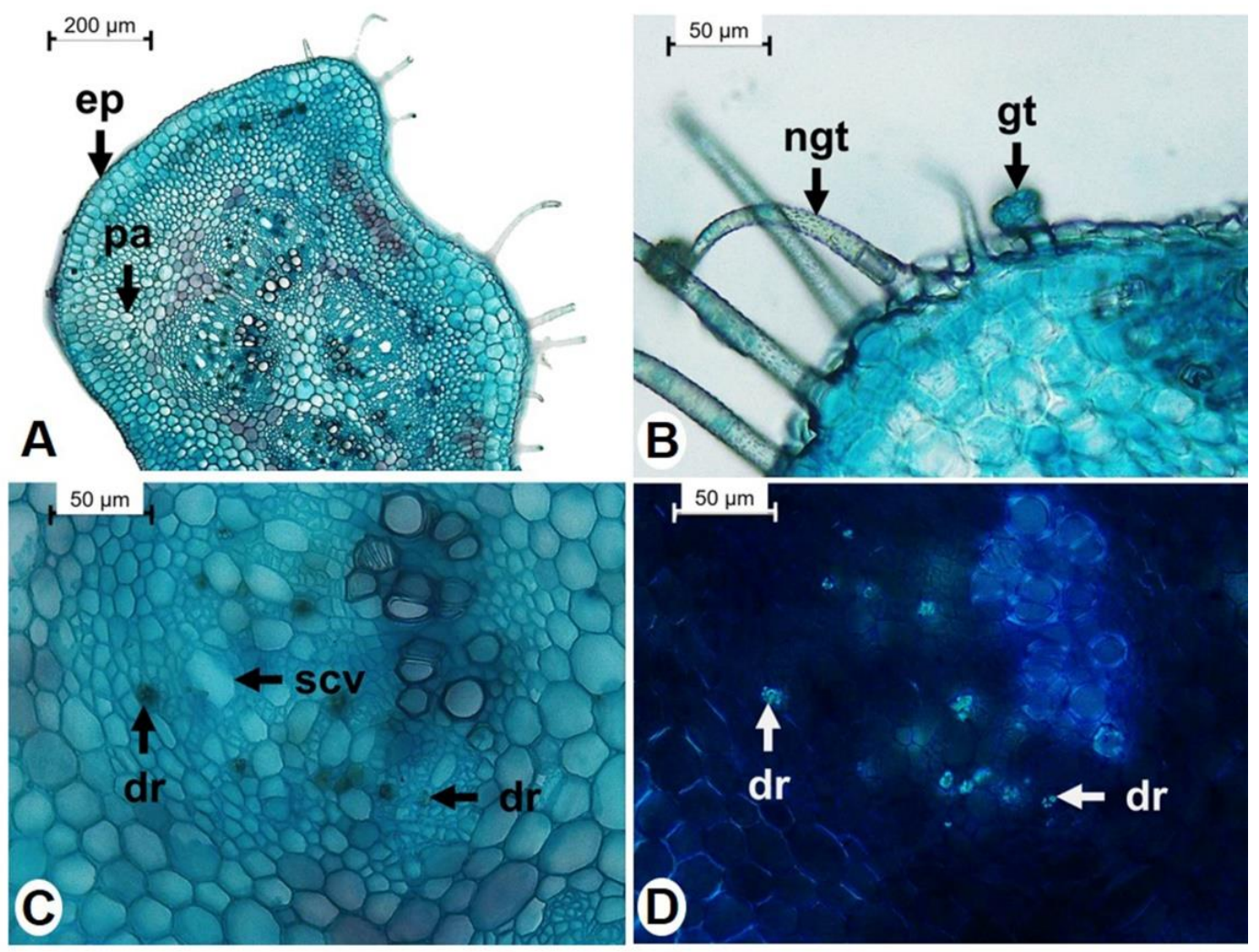

Figure 1. Cross-sections of the petiolule of Spondias purpurea. A-C. optical microscopy; D. polarized microscopy; A. detail of epidermis (ep) and parenchyma (pa); B. detail of non-glandular trichome (ngt) and glandular trichome (gt); C,D. secretory cavity (scv) and druses (dr) in the phloem. Font: Santos et al. (2020).

There is a controversy in the literature for the leaflets of S. mombin. In the frontal view, the leaflets present cells of straight or slightly sinuous contour in both faces (Figure $2 \mathrm{AB}$ ). It is classified as amphistomatic, with anomocytic stomata in both faces (Figure. 2AB). Spondias tuberosa and S. dulcis presented hypostomatic leaflets (Nascimento-Silva \& Paiva, 2007; Lima, Magalhães \& Randau, 2020). Chisom, Chukwu \& Okeke (2014) classified it as amphistomatic, and Vasconcelos, Vasconcelos \& Randau (2016) classified it as hypostomatic. There are nonglandular trichomes on the adaxial face (Figure 2A) and glandular trichomes on the abaxial face (Figure 2C). Spondias mombin had only nonglandular trichomes on both faces while $S$. dulcis had non-glandular trichomes on the abaxial face (Vasconcelos, Vasconcelos \& Randau, 2016; Lima, Magalhães \& Randau, 2020).

The midrib has a concave-convex contour and uniseriate epidermis in cross-section, covered by a cuticle (Figure 2D). The same midrib contour was observed in $S$. dulcis Parkinson (Lima, Magalhães \& Randau, 2020). Spondias mombin presented a biconvex contour midrib (Vasconcelos, Vasconcelos \& Randau, 2016). The palisade parenchyma fills in the midrib on the adaxial side (Figure 2D). The abaxial side is filled with parenchyma (Figure 2D). There are two collateral vascular bundles in the central region, one of which is larger and faces the abaxial side. The other bundle is smaller and faces the adaxial side (Figure 2D). Four collateral vascular bundles were visualized in $S$. dulcis and three in S. mombin, being one bundle is larger, and two bundles are accessories (Vasconcelos, Vasconcelos \& Randau, 2016; Lima, Magalhães \& Randau, 2020). As in the petiolule, secretory cavities and druses were found in the phloem (Figure 2EF). In $S$. cytherea (synonym of $S$. dulcis) and S. pinnata, the druses are located in the phloem and the midrib parenchyma (Norfaizal \& Latiff, 2013). In $S$. mombin, the druses are located only in the midrib parenchyma (Vasconcelos, Vasconcelos \& Randau, 2016).

The mesophyll is dorsiventral, with one layer of palisade parenchyma and about six layers of spongy parenchyma, with few intercellular spaces (Figure 2G). Spondias cytherea and $S$. pinnata have only one layer of palisade parenchyma (Norfaizal \& Latiff, 2013), while $S$. mombin presented two layers of palisade parenchyma near the midrib and one layer near the margin of the leaflets (Vasconcelos, Vasconcelos \& Randau, 2016). Druses are present in the mesophyll (Figure 2GH). Lima, Magalhães \& Randau (2020) also found druses in the mesophyll of $S$. dulcis. 

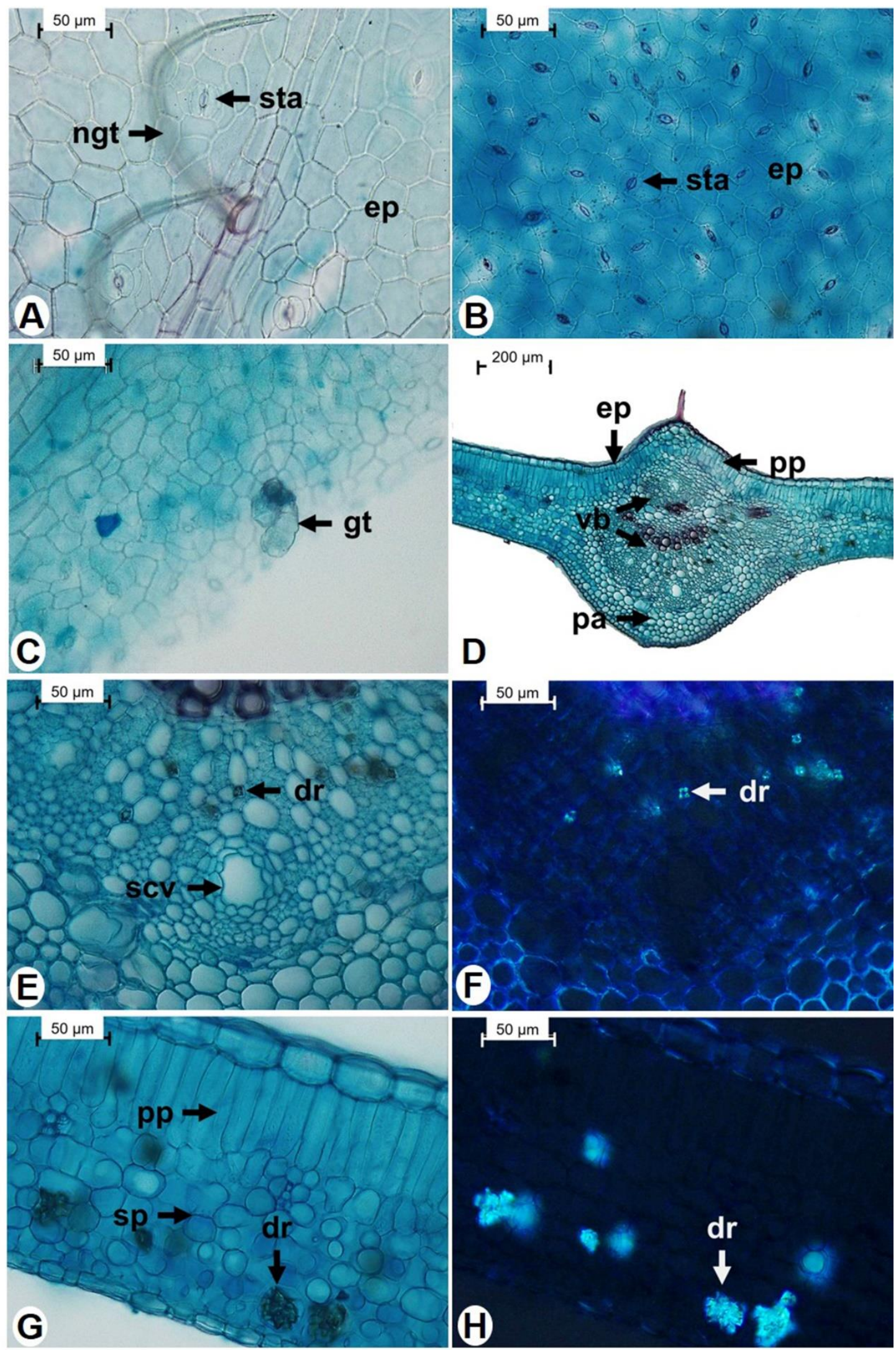

Figure 2. Paradermal and cross-sections of the leaflets of Spondias purpurea. A-E,G. optical microscopy; F,H. polarized microscopy; A. adaxial face, showing epidermis (ep), stomata (sta), and non-glandular trichome (ngt); B,C. abaxial face, showing epidermis (ep), stomata (st), and glandular trichome (gt); D-F. midrib showing epidermis (ep), palisade parenchyma (pp), parenchyma (pa) and vascular bundles (vb); G,H. mesophyll showing palisade parenchyma (pp), spongy parenchyma (sp), and druses (dr). Font: Santos et al. (2020). 
Figure $3 \mathrm{AB}$ shows the leaflets, in crosssection, without any treatment. Phenolic compounds were found in the epidermis (Figure 3C), spongy parenchyma (Figure 3C), palisade parenchyma (Figure 3D), and midrib parenchyma (Figure 3D). In S. mombin, phenolic compounds were found only in the palisade parenchyma (Vasconcelos, Vasconcelos \& Randau, 2016). In S. tuberosa they were found in the trichomes and the parenchyma sheath (Nascimento-Silva, Chinalia \& Paiva, 2008). Phenolic compounds have been identified in the leaves of $S$. purpurea, such as quercetin 3-O-rutinoside (Pereira et al., 2015), caffeic acid, and epigallocatechin (Almeida et al., 2017). The latter two compounds were correlated with antioxidant and anti-ulcer properties of the species' leaves (Almeida et al. 2017).
Alkaloids were identified in the central vein parenchyma (Figure 3E). In $S$. tuberosa, alkaloids were also identified in the parenchyma (Nascimento-Silva, Chinalia \& Paiva, 2008). The test to identify alkaloids was negative in $S$. mombin (Vasconcelos, Vasconcelos \& Randau, 2016). Tannins were observed in the midrib parenchyma (Figure 3F), in the cells around the secretory cavities (Figure 3G), in the palisade parenchyma (Figure $3 \mathrm{H}$ ), and the spongy parenchyma (Figure 3I). In S. tuberosa the tannins were observed in the parenchymal sheath (Nascimento-Silva, Chinalia \& Paiva, 2008). In S. mombin, these compounds were not identified (Vasconcelos, Vasconcelos \& Randau, 2016).

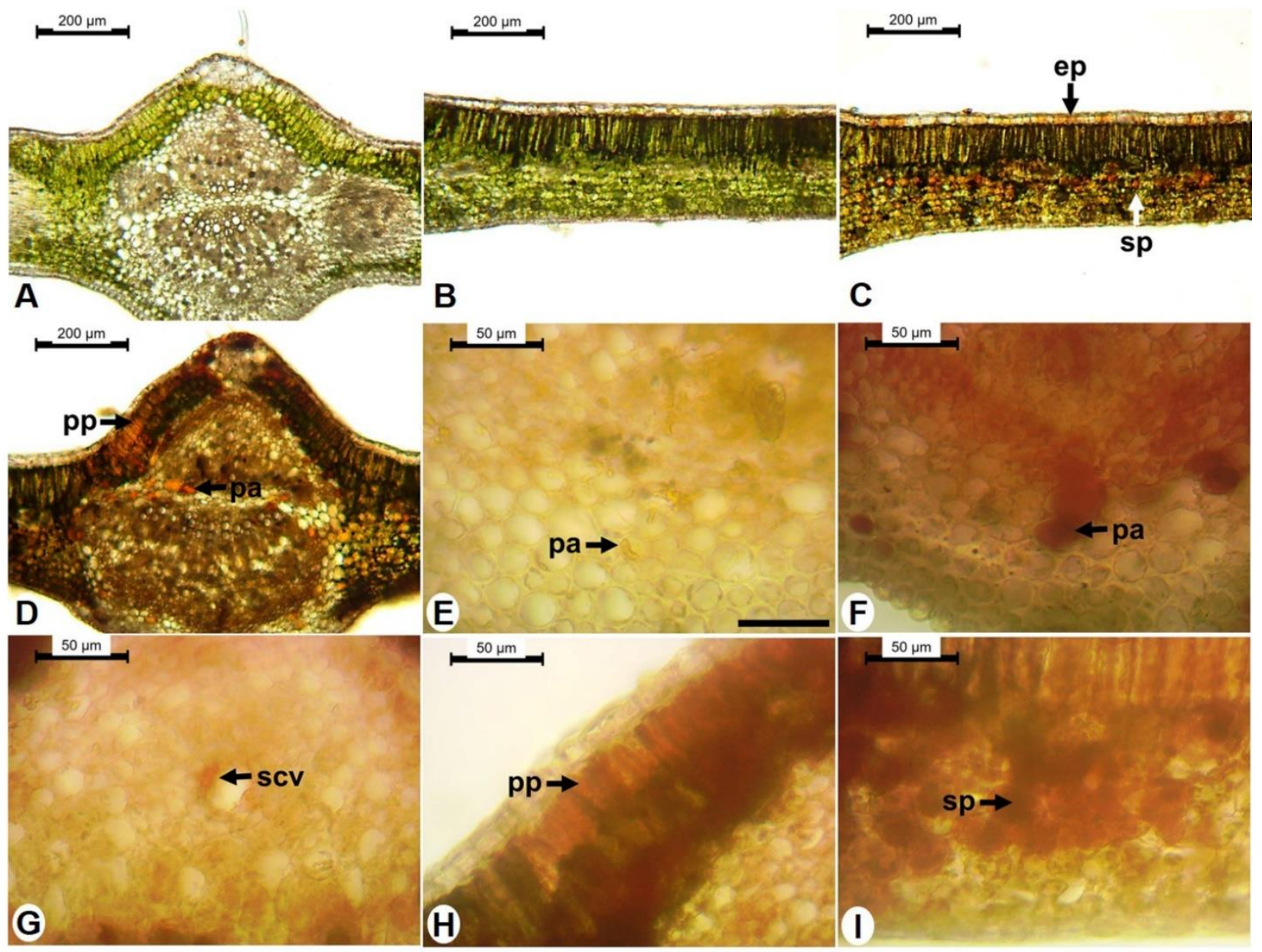

Figure 3. Histochemistry of the leaflets of Spondias purpurea. A,B. control; C,D. Potassium dichromate (10\%) - phenolic compounds in the epidermis (ep), palisade parenchyma (pp), spongy parenchyma (sp), and parenchyma (pa); E. Dragendorff's reagent - alkaloids in the parenchyma (pa); F-I. Vanillin chloridric - tannins in the parenchyma (pa), in the cells around the secretory cavity (scv), in palisade parenchyma (pp), and spongy parenchyma (sp). Font: Santos et al. (2020).

Triterpenes and steroids were visualized in the midrib parenchyma (Figure 4A) and the spongy parenchyma (Figure 4B). Marisco et al. (2017a) identified some terpenes in the leaves of $S$. purpurea, such as spathulenol, linolenic acid, transcaryophyllene, and alpha-muurolene. The fraction containing these terpenes showed antifungal activity against Moniliophthora perniciosa. Lipophilic compounds were evident in the cuticle (Figure 4C). Essential oils were found 
in the secretory cavities (Figure 4D), in the midrib parenchyma (Figure 4D), and the palisade parenchyma (Figure 4E). Lemos et al. (1995) identified $\beta$-caryophyllene and $\delta$-cadinol as major components of the essential oil of leaves of this species. However, Lima, Oliveira \& Brito (2016) found the content of only $2.35 \%$ de $\beta$ caryophyllene, with heptacosano $(28.80 \%)$ as the major constituent of the essential oil of the leaves of $S$. purpurea.

Lignin was evidenced in the conductive cell wall, xylem fibers (Figure 4F), and starch grains observed in the midrib parenchyma (Figure
4G). Vasconcelos, Vasconcelos \& Randau (2016) also evidenced starch grains in the central vein parenchyma of $S$. mombin, while NascimentoSilva, Chinalia \& Paiva (2008) evidenced starch grains in the mesophyll of $S$. tuberosa. The test with hydrochloric acid $(10 \%)$ showed that the druses are of calcium oxalate, after their dissolution, without forming bubbles (Figure 4HI). Histochemical tests with $S$. mombin (Vasconcelos, Vasconcelos \& Randau, 2016) and S. tuberosa (Nascimento-Silva, Chinalia \& Paiva, 2008) also confirmed that the chemical composition of the crystals present in the species is calcium oxalate.

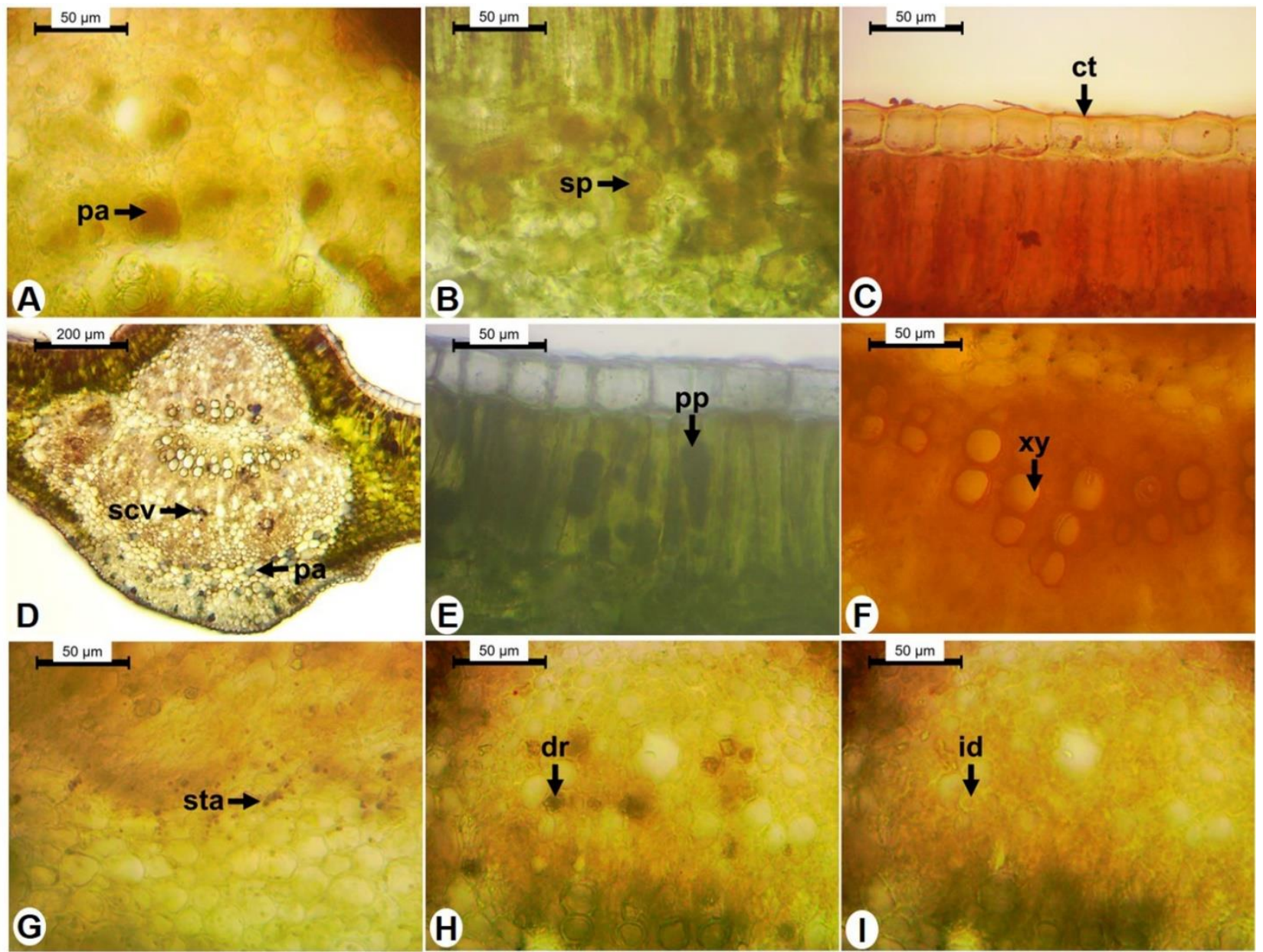

Figure 4. Histochemistry of the leaflets of Spondias purpurea. A,B. Antimony trichloride - triterpenes and steroids in the parenchyma (pa) and spongy parenchyma (sp); C. Sudan III - lipophilic compounds in the cuticle (ct); D,E. Nadi reagent - essential oils in parenchyma (pa), secretory cavities (scv) and palisade parenchyma (pp); F. Phloroglucinol - lignin in xylem (xy); G. Lugol - starch (sta) in parenchyma; H,I. Hydrochloric acid $(10 \%)$ - druse (dr) and idioblast (id) that contained druse. Font: Santos et al. (2020).

Table 1 and Table 2 summarize the main results, comparing with literature data about other species of Spondias. 
Table 1. Anatomical characters of Spondias species. ${ }^{1}$ Lima, Magalhães \& Randau (2020); ${ }^{2}$ Norfaizal \& Latiff (2013); ${ }^{30}$ Vasconcelos, Vasconcelos \& Randau (2016); ${ }^{4}$ Chisom, Chukwu \& Okeke (2014); ${ }^{5}$ Nascimento-Silva \& Paiva (2007). Font: Santos et al. (2020).

\begin{tabular}{|c|c|c|c|c|c|c|}
\hline \multicolumn{2}{|c|}{ Characters } & $\begin{array}{l}\text { Spondias } \\
\text { cytherea } \\
\text { (S. dulcis) }\end{array}$ & $\begin{array}{l}\text { Spondias } \\
\text { mombin }\end{array}$ & $\begin{array}{l}\text { Spondias } \\
\text { pinnata }\end{array}$ & $\begin{array}{l}\text { Spondias } \\
\text { purpurea }\end{array}$ & $\begin{array}{l}\text { Spondias } \\
\text { tuberosa }\end{array}$ \\
\hline \multirow{3}{*}{$\begin{array}{l}\stackrel{0}{\Xi} \\
.0 \\
.0 \\
0 \\
0\end{array}$} & $\begin{array}{l}\text { 芯 } \\
\text { 离 }\end{array}$ & -- & $\begin{array}{l}\text { convex with } \\
\text { undulation }^{3}\end{array}$ & -- & $\begin{array}{c}\text { concave-convex } \\
\text { with two small } \\
\text { lateral } \\
\text { projections on } \\
\text { the adaxial side }\end{array}$ & -- \\
\hline & 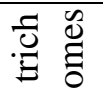 & -- & non-glandular ${ }^{3}$ & -- & $\begin{array}{l}\text { non-glandular } \\
\text { and glandular }\end{array}$ & -- \\
\hline & $\sum_{E}^{\infty} \infty$ & -- & $\begin{array}{l}\text { located close to } \\
\text { the epidermis }{ }^{3}\end{array}$ & -- & $\begin{array}{l}\text { located in } \\
\text { phloem }\end{array}$ & -- \\
\hline \multirow{6}{*}{ 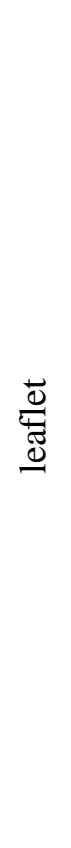 } & 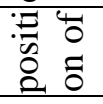 & hypostomatic $^{1}$ & $\begin{array}{l}\text { amphistomatic } \\
\text { hypostomatic }^{3}\end{array}$ & -- & amphistomatic & hypostomatic $^{5}$ \\
\hline & $\begin{array}{l}\stackrel{0}{\mathscr{\Xi}} \\
\frac{0}{0} \\
\stackrel{\Xi}{\Xi}\end{array}$ & $\begin{array}{c}\text { non-glandular } \\
\text { on the abaxial } \\
\text { face }^{1}\end{array}$ & $\begin{array}{c}\text { non-glandular on } \\
\text { both faces }\end{array}$ & -- & $\begin{array}{l}\text { non-glandular } \\
\text { on the adaxial } \\
\text { face and } \\
\text { glandular on the } \\
\text { abaxial face }\end{array}$ & -- \\
\hline & م & $\begin{array}{l}\text { concave- } \\
\text { convex }\end{array}$ & biconvex $^{3}$ & -- & concave-convex & -- \\
\hline & $\tilde{D}$ & four $^{1}$ & three $^{3}$ & -- & two & -- \\
\hline & 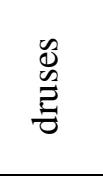 & $\begin{array}{c}\text { mesophyll }^{1} ; \\
\text { midrib } \\
\text { parenchyma and } \\
\text { phloem }^{2} \\
\end{array}$ & $\begin{array}{c}\text { midrib } \\
\text { parenchyma }^{3}\end{array}$ & $\begin{array}{l}\text { phloem and } \\
\text { midrib } \\
\text { parenchyma }\end{array}$ & $\begin{array}{l}\text { phloem and } \\
\text { mesophyll }\end{array}$ & -- \\
\hline & 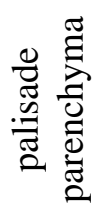 & one layer $^{2}$ & $\begin{array}{l}\text { two layers near } \\
\text { the midrib and } \\
\text { one layer near the } \\
\text { margin of the leaf } \\
\text { blade }^{3}\end{array}$ & one layer $^{2}$ & one layer & -- \\
\hline
\end{tabular}

Table 2. Histochemical characters of Spondias species. ${ }^{1}$ Vasconcelos, Vasconcelos \& Randau (2016); ${ }^{2}$ Nascimento-Silva, Chinalia \& Paiva (2008). Fonte: Santos et al. (2020).

\begin{tabular}{|c|c|c|c|}
\hline Characters & $\begin{array}{l}\text { Spondias } \\
\text { mombin }\end{array}$ & Spondias purpurea & Spondias tuberosa \\
\hline phenolic compounds & $\begin{array}{c}\text { palisade } \\
\text { parenchyma }^{1}\end{array}$ & $\begin{array}{l}\text { epidermis, spongy parenchyma, } \\
\text { palisade parenchyma, and midrib } \\
\text { parenchyma }\end{array}$ & $\begin{array}{c}\text { trichomes and } \\
\text { parenchyma sheath }\end{array}$ \\
\hline alkaloids & negative $^{1}$ & midrib parenchyma & parenchyma $^{2}$ \\
\hline tannins & negative $^{1}$ & $\begin{array}{c}\text { midrib parenchyma, cells around } \\
\text { the secretory cavities, palisade } \\
\text { parenchyma, and spongy } \\
\text { parenchyma }\end{array}$ & parenchyma sheath $^{2}$ \\
\hline triterpenes and steroids & -- & $\begin{array}{l}\text { midrib parenchyma and spongy } \\
\text { parenchyma }\end{array}$ & -- \\
\hline lipophilic compounds & -- & cuticle & -- \\
\hline essential oils & -- & $\begin{array}{c}\text { secretory cavities, midrib } \\
\text { parenchyma, and palisade } \\
\text { parenchyma }\end{array}$ & -- \\
\hline lignin & -- & xylem & -- \\
\hline starch grains & $\begin{array}{c}\text { midrib } \\
\text { parenchyma }^{1}\end{array}$ & midrib parenchyma & mesophyll $^{2}$ \\
\hline
\end{tabular}


chemical composition of the crystals calcium

oxalate $^{1}$

calcium oxalate

calcium oxalate $^{2}$

\section{Conclusion}

This study provides the main characters for the identification of the species, such as petiolule with concave-convex shape, non-glandular and glandular trichomes, druses in phloem; leaflets amphistomatic, with non-glandular trichomes on the adaxial face and glandular trichomes on the abaxial face, midrib with concave-convex shape, two collateral vascular bundles, one layer of palisade parenchyma, druses in phloem and mesophyll. Moreover, it was possible to demonstrate the accumulation site of the different metabolites present in the species, contributing to the taxonomy of the genus Spondias.

\section{Acknowledgements}

The authors are grateful to Conselho Nacional de Desenvolvimento Científico e Tecnológico (CNPq) for research funding (409452/016-5).

\section{References}

Alencar, L. C. B.; Chaves, T. P.; Santos, J. S.; Nóbrega, F. P.; Araújo, R. M.; Santos, V. L.; Felismino, D. C.; Medeiros, A. C. D. 2015. Efeito modulador do extrato de plantas medicinais do gênero Spondias sobre a resistência de cepas de Staphylococcus aureus à eritromicina. J. Appl. Pharm. Sci., $36,1,111-116$.

Almeida, C. L. F.; Brito, S. A.; Santana, T. I.; Costa, H. B. A.; Carvalho Júnior, C. H. R.; Silva, M. V.; Almeida, L. L.; Rolim, L. A.; Santos, V. L.; Wanderley, A. G.; Silva, T. G. 2017. Spondias purpurea L. (Anacardiaceae): antioxidant and antiulcer activities of the leaf hexane extract. Oxidative Med. Cell. Longev., 2017, 1-14. doi: $10.1155 / 2017 / 6593073$

APG IV. 2016. An update of the Angiosperm Phylogeny Group classification for the orders and families of flowering plants: APG IV. Bot. J. Linn. Soc., 181, 1-20. doi: 10.1111/boj.12385

Borges, R. M.; Moreira, R. P. M. 2016. Estudo etnobotânico de plantas medicinais no município de Confresa Mato Grosso, Brasil. Biodiversidade, 15, 3, 68-82.

Bukatsch, F. 1972. Bemerkungen zur Doppelfärbung Astrablau-Safranin. Mikrokosmos, 61, 255.

Castro, J. A.; Brasileiro, B. P.; Lyra, D. H.; Pereira, D. A.; Chaves, J. L. 2011. Ethnobotanical study of traditional uses of medicinal plants: the flora of caatinga in the community of Cravolândia-BA, Brazil. J. Med. Plants Res., 5, 10, 1905-1917.

Chisom, I. F.; Chukwu, N. O.; Okeke, C. U. 2014. A comparative foliar anatomical and morphological study on Anacardium occidentale L. and Spondias mombin L. Int. J. Herb. Med., 2, 2, 150-153.

Dantas, L. M.; Sá, R. D.; Pereira, L. B. S.; Randau, K. P.; Silva, F. C. L. 2019. Caracterização anatômica e histoquímica de Schinus molle L. In: Lopes, L. B. M.; Melo, T. S. (org.). Biomedicina e Farmácia: Aproximações 2. Ponta Grossa: Editora Atena, pp. 214-225.

David, R.; Carde, J. P. 1964. Coloration différentielle dês inclusions lipidique et terpeniques dês pseudophylles du Pin maritime au moyen du reactif Nadi. C. R. Acad. Sci. Paris, Ser. D, 258, 1338-1340.

Fortuny-Fernández, N. M.; Ferrer, M. M.; RuenesMorales, M. D. R. 2017. Centros de origen, domesticación y diversidad genética de laciruela mexicana, Spondias purpurea (Anacardiaceae). Acta Bot. Mex., 121, 7-38. doi: 10.21829/abm121.2017.1289

Franco, E. A. P.; Barros, R. F. M. 2006. Uso e diversidade de plantas medicinais no Quilombo Olho D'água dos Pires, Esperantina, Piauí. Rev. Bras. Plantas Med., 8, 3, 78-88.

Freitas, A. V. L.; Coelho, M. D. F. B.; Maia, S. S. S.; Azevedo, R. A. B. 2012. Plantas medicinais: um estudo etnobotânico nos quintais do Sítio Cruz, São Miguel, Rio Grande do Norte, Brasil. Rev. Bras. Biociênc., 10, 1, 48-59.

Jensen, W. A. 1962. Botanical histochemistry, principles and practice. San Francisco: W.H. Freeman and Company.

Johansen, D. A. 1940. Plant microtechnique. New York: McGraw-Hill Book Company Inc.

Kraus, J. E.; Arduin, M. 1997. Manual básico de métodos em morfologia vegetal. Rio de Janeiro: Editora da Universidade Federal Rural do Rio de Janeiro, Seropédica.

Krauter, D. 1985. Erfahrungen mit Etzolds FSAFärbung für Pflanzenschnitte. Mikrokosmos, 74, 8Pq, 231-233.

Lemos, T. L. G.; Nogueira, P. C.L.; Alencar, J. W.; Craveiro, A. A. 1995. Composition of the leaf oils of four Spondias species from Brazil. J. Essent. Oil. Res., 7, 561-563. doi: 10.1080/10412905.1995.9698588 
Lima, E. Q.; Oliveira, E.; Brito, H. R. 2016. Extraction and characterization of the essential oils from Spondias mombin L. (Cajá), Spondias purpurea L. (Ciriguela) and Spondias sp (Cajarana do serto). Afr. J. Agric. Res., $\quad 11, \quad 2, \quad 105-116 . \quad$ doi: 10.5897/AJAR2014.10363

Lima, S. E. B. M.; Magalhães, C. S.; Randau, K. P. 2020. Anatomic characterization of the foliar blade of Spondias dulcis Parkinson. Am. J. Biotechnol. Biosci., 3, 18.

Lorenzi, H.; Lacerda, M. T. C.; Bacher, L. B. 2015. Frutas no Brasil: nativas e exóticas (de consumo in natura). São Paulo: Instituto Plantarum de Estudos da Flora.

Mace, M. E.; Bell, A. A.; Stipanovic, R. D. 1974. Histochemistry and isolation of gossypol and related terpenoids in root of cotton seedlings. Phytophatol., 64, 1297-1302. doi: 10.1094/Phyto-64-1297

Mace, M. Z.; Howell, C. R. 1974. Histochemistry and identification of condensed tannin precursors in roots of cotton seedlings. Can. J. Bot., 52, 2423-2426. doi: 10.1139/b74-314

Marisco, G.; Pungartnik, C. 2015. Spondias purpurea L. (Anacardiaceae): traditional uses, chemical composition and biological activities. Scientia Amazonia, 4, 2, 10-18.

Marisco, G.; Santos, R. X.; Aguiar, R.; Brendel, M.; Pungartnik, C. 2017a. Antifungal potential of terpenes from Spondias purpurea L. leaf extract against Moniliophthora perniciosa that causes witches broom disease of Theobroma cacao. Int. J. Complement. Altern. Med., 7, 1, 2-6.

Marisco, G.; Silva, T. S. S.; Assunção, R.; Brendel, M.; Pungartnik, C. 2017b. The use of herbal medicine in a rural community in Vitória da Conquista, Bahia, Brazil: an indication for pharmacological studies. Int. J. Complement. Altern. Med., 7, 1, 1-11. doi: 10.15406/ijcam.2017.07.00214

Metcalfe, R.; Chalk, L. 1950. Anatomy of the dicotyledons: leaves, stem, and wood in relation to taxonomy with notes on economic uses. Oxford: Clarendon Press.

Miranda-Cruz, E.; Espinosa-Moreno, J.; Centurión-Hidalgo, D.; Valázquez-Martínez, J. R.; Alor-Chávez, M. J. 2012. Actividad antimicrobiana de extractos de Psidium friedrichsthalianum L., Pterocarpus hayesii L., Tynanthus guatemalensis L. y Spondias purpurea L. Bol. Latinoam. Caribe Plantas Med. Aromát., 11, 4, 354-361.

Mitchell, J. D.; Daly, D. C. 2015. A revision of Spondias L. (Anacardiaceae) in the
Neotropics. PhytoKeys,v. 55, p. 1-92, 2015. doi: 10.3897/phytokeys.55.8489

Nascimento-Silva, O.; Paiva, J. G. A. 2007. Estudos morfológicos e anatômicos em folhas adultas de Spondias tuberosa Arruda (Anacardiaceae Lindley). Bol. Latinoam. Caribe Plantas Med. Aromát., 6, 2, 36-43.

Nascimento-Silva, O.; Chinalia, L. A.; Paiva, J. G. A. 2008. Caracterização histoquímica dos folíolos de Spondias tuberosa Arruda (Anacardiaceae Lindl.). Caatinga, 21, 3, 6268.

Norfaizal, G. M.; Latiff, A. 2013. Leaf anatomical characteristics of Bouea, Mangifera and Spondias (Anacardiaceae) in Malaysia. AIP Conf. Proc., 1571, 394-403. doi: 10.1063/1.4858690

Oliveira, F. C. S.; Barros, R. F. M.; Moita Neto, J. M. 2010. Plantas medicinais utilizadas em comunidades rurais de Oeiras, semiárido piauiense. Rev. Bras. Plantas Med., 12, 3, 282-301. doi: 10.1590/S151605722010000300006

Pell, S. K.; Mitchell, J. D.; Miller, A. J.; Lobova, T. A. 2011. Anacardiaceae. In: Kubitzki, K. Eudicots: Sapindales, Cucurbitales, Myrtaceae. India:Springer-Verlag Berlin Heidelberg, pp. 7-50.

Pereira, C.; Oliveira, L. L. D.; Gonçalves, R.; Amaral, A. C. F.; Kuster, R. M.; Sakuragui, C. M. 2015. Phytochemical and phylogenetic analysis of Spondias (Anacardiaceae). Química Nova, 38, 6, 813-816. doi: 10.5935/0100-4042.20150087

Sameh, S.; Al-Sayed, E.; Labib, R. M.; Singab, A. N. 2018. Genus Spondias: a phytochemical and pharmacological review. Evid. Based Complement. Alternat. Med., 2018, 1-13. doi: 10.1155/2018/5382904

Santos, R. S.; Santos, R. X.; Silva, G. 2017. Avaliação da atividade genotóxica, citotóxica e antimicrobiana da infusão das folhas de Spondias purpurea L. Scientia Plena, 13, 3, 19. doi: 10.14808/sci.plena.2017.039901

SASS, J. E. 1951. Botanical microtechnique. Ames: The Iowa State College Press.

Sá, R. D.; Cavalcanti, G. S.; Santos, D. M.; Silva, A. S.; Padilha, R. J. R.; Alves, L. C.; Randau, K. P. 2019. Anatomical characterization, histochemistry, and crystal analysis of the leaf blade of Mangifera indica L. J. Environ. Anal. Prog., 4, 4, 266-272. doi: 10.24221/JEAP.4.4.2019.2631.266-272

Schulze-Kaysers, N.; Feuereisen, M. M.; Schieber, A. 2015. Phenolic compounds in edible species of the Anacardiaceae family-a review. 
RSC Adv., 5, 73301-73314. doi: 10.1039/C5RA11746A

Silva, G. A.; Brito, N. J. N.; Santos, E. C. G.; Lópes, J. A.; Almeida, M. G. 2014. Gênero Spondias: aspectos botânicos, composição química e potencial farmacológico. J. Biol. Pharm. Agric. Management., 10, 1, 27-41.

Silva, N. C. B.; Regis, A. C. D.; Esquibel, M. A.; Santos, J. E. S.; Almeida, M. Z. 2012. Uso de plantas medicinais na comunidade quilombola da Barra II-Bahia, Brasil. Bol. Latinoam. Caribe Plantas Med. Aromát., 11, 5, 435-453.

Silva-Luz, C. L.; Pirani, J. R. 2015. Anacardiaceae in Lista de Espécies da Flora do Brasil. Jardim
Botânico do Rio de Janeiro. Available in: http://floradobrasil.jbrj.gov.br/jabot/floradob rasil/FB44. Accessed in: April 17, 2020.

Vasconcelos, A. L.; Vasconcelos, A. L.; Randau, K. P. 2016. Pharmacognostic characterization of Spondias mombin L. (Anacardiaceae). Pharmacogn. J., 8, 6, 513-519. doi: 10.5530 / pj.2016.6.1

Yoder, L. R.; Mahlberg, P. G. 1976. Reactions of alkaloid and histochemical indicators in laticifers and specialized parenchyma cells of Catharanthus roseus (Apocynaceae). Am. J. Bot., 63, 9, 1167-1973. doi: 10.1002/j.15372197.1976.tb13202.x 